\title{
anemon
}

Muş Alparslan Üniversitesi Sosyal Bilimler Dergisi

Journal of Social Sciences of Muş Alparslan University

Yı//Year: 2016 • Cilt/Volume: 4 • Sayı/Number: 2

ISSN: 2147-7655 • e-ISSN: 2149-4622

ÖZGÜN ARASTTIRMA O ORIGINAL ARTICLE

\section{Yeni Medyanın Gündelik Yaşama Etkileri: "armut.com" ve "evebirilazim.com" Örnekleri ile Çevrimiçi Hizmet Satın Alma Pratiği}

\author{
Ceren YEGEN ${ }^{1, a}$ \\ ${ }^{1}$ Arş. Gör., Muş Alparslan Üniversitesi, İletişim Fakültesi, Gazetecilik Bölümü, Muş/ Türkiye \\ Başvuru tarihi: 06 Mart 2016 Düzeltme tarihi: 27 Mayıs 2016 Kabul tarihi: 03 Haziran 2016
}

Öz

Günümüzde yeni medya üzerine yapılan birçok çalışma onun güncel etkilerini ve meydana getirdiği değişiklikleri konu almaktadır. Birçok alan gibi gündelik yaşamı da etkileyen yeni medya uygulamaları kişilerarası iletişimden, bireysel pratiklere kadar çok sayıda duruma etki etmiş̧tir. Öyle ki; armut.com ve evebirilazim.com gibi çevrimiçi hizmet siteleri ortaya çıkmış, bireyler hizmet ya da eleman temini noktasında etraflarına sorarak bir eleman bulmak ya da hizmet edinmek yerine, bu sitelere başvurmaya başlamıştır. Bu yüzden bu çalışmanın konusu çevrimiçi hizmet satın alma pratiğinin, çevrimiçi hizmet temini sağlayan armut.com ile evebirilazim.com internet siteleri örnekleri ile açıklanmasıdır. Çalışmanın amacı hem hizmet satın almak isteyen, hem de hizmet temin eden kimseleri ortak bir çatı altında buluşturan çevrimiçi hizmet satın alma sitelerinin belirlediği, yeni ve önemli değişimin ele alınmasıdır. İçerik çözümlemesi tekniğinin kullanıldığı çalışmada, armut.com ve evebirilazim.com siteleri incelenmiş ve çevrimiçi hizmet satın almanın söz konusu siteler üzerinden nasıl gerçekleştiği açıklanmaya çalışılmıştır.

\section{Anahtar Kelimeler}

Yeni Medya, Çevrimiçi Hizmet, Gündelik Yaşam, armut.com, evebirilazim.com.

a Sorumlu Yazar/Correspoding Author: Muş Alparslan Üniversitesi Kampüsü, İletişim Fakültesi, Gazetecilik Bölümü, Diyarbakır Yolu 7. Km, 49250, Muş / Türkiye.

e-posta: c.yegen@alparslan.edu.tr 


\title{
New Media's Effects on Daily Life: The Practise of Purchasing Online Services with Examples of "armut.com" and "evebirilazim.com"
}

\begin{abstract}
Nowadays many studies on new media are about its current affects and the changes it creates. New media applications which affect daily life, like many fields, have had an impact on both interpersonal communication and individual practices. Such that, online service websites like armut.com and evebirilazim.com have occured, hereby individuals began to consult to find an employee or service via these websites instead of asking people around and having service. Thus, this study's subject is to explain the purchase online services with the examples of armut.com and evebirilazim.com websites which provide the recruitment of online services. The study's aim is discussing the new and substantial fluctuation which is determined by online service purchasing websites and which gathers up both service sellers and service purchasers under a common roof. In the study, content analysis was used, armut.com and evebirilazim.com websites were examined and how the online services purchasing comes true via armut.com and evebirilazim.com websites has been explained.
\end{abstract}

Keywords

New Media, Online Services, Daily Life, armut.com, evebirilazim.com.

\section{GÍRIŞ}

İletişim teknolojileri günden güne gelişmektedir. Yeni medya geleneksel medyanın birçok bağlamda önüne geçerken, bireysel birçok alışkanlık ve eyleme de farklı biçimler getirmiştir. Bu yüzden bu çalışmanın konusu, yeni medyanın gündelik yaşama etkilerinin internet üzerinden çevrimiçi hizmet satın alma temelinde ele alınmasıdır. Bu anlamda armut.com ve evebirilazim.com gibi iki çevrimiçi hizmet satın alma sitesinin biçimsel ve işlevsel olarak incelenmesi amaçlanmıştır. Bu şekilde yeni medyanın gündelik yaşam pratiklerini nasıl etkilediği söz konusu sitelerin varlık ve uygulamaları ile ortaya konduğundan, çalışmanın yeni medya tartışmalarına sağlayacağı katkının da büyük olduğu düşünülmektedir.

Yeni medyanın gündelik yaşam içerisinde dönüştürdüğü alanlara dikkat çeken çalışma, bu anlamda bir hayli önemlidir. Çalışma ayrıca, Türkiye'de çevrimiçi uygulama ve hizmetlerin nasıl yaygınlaştığının ve geliştiğinin anlaşılması açısından da önem arz etmektedir. 
Çalışmada kullanılacak olan yöntem içerik analizidir. İncelenecek olan siteler armut.com ve evebirilazim.com çalışma kapsamında ayrıntılı olarak analiz edilecek ve elde edilen veriler sistematik biçimde yorumlanacaktır. Veri toplama tekniği olarak söz konusu sitelerde bireysel tarama yapılacak, veriler yazarlar tarafından arşivlenecektir.

Çalışmanın kuramsal çerçevesini yeni medya tartışmaları oluşturacak iken, kapsam ve sınırları, sağlıklı veriler elde edebilmek adına yalnızca armut.com ve evebirilazim.com gibi iki çevrimiçi hizmet satın alma sitesi oluşturacaktır. Söz konusu siteler yazarlar tarafından Türkiye'de çevrimiçi hizmet bağlamında en fazla öne çıktıkları düşünülen siteler olduklarından yargısal örneklem ile tercih edilmiş ve incelenmiştir.

\section{YENI MEDYA}

Günümüzde geldiğimiz noktada, hemen her eylemin yeni medya üzerinden yapıldığı toplumsal arenada yeni medyanın ne olduğunu anlamak çok önemlidir. Yeni medyadan kasıtla yeni iletişim araçları anlaşılmamalıdır. Çünkü yeni medya kavramı, yeni nesil iletişim araçları ile birlikte sağlanan yeni iletişim ortamlarını nitelemektedir (Crosbie, 1998).

Yeni medya geleneksel medyadan teknolojik farklılıklarla ayrılmaktadır. Yeni medyanın kod çevrimi, değişkenlik, otomasyon (makineleşme, özdevinim), modülerlik ve sayılarla gösterme özelliklerine dikkat çeken Lev Manovich'e göre de yeni medya, geleneksel olan eski medyadan bazı noktalarda farklılık göstermektedir ve buradaki anahtar fark yeni medyanın programlanabilir olmasıdır. Sayısal temelde biçimlenmiş yeni medya çevrimiçi formülasyonu ile geleneksel medyaya göre daha hızlı, etkileşimli ve eş zamanlı faaliyet göstermektedir (Sorapure, 2004: 1-5).

Manovich (2001: 43), ne olduğu sıkça sorgulanan yeni medyanın; internet, bilgisayar, web siteleri, bilgisayar oyunları gibi olguları içeren bir iletişim ortamı olduğunu ifade etmektedir.

Birilerinin davet yollaması sureti ile katılınan ve özel üyelik gösteren ASmallWorld, herkese açık olan Facebook ve profesyonel odaklı LinkedIn gibi platformların yanında (Papacharissi, 2009: 199), Youtube, Pinterest, Badoo, Google+, Foursquare ve Tumblr gibi sosyal ağlar da önce çıkmakta ve bireyler tarafindan farklı amaçlar için kullanılmaktadır.

Çevrimiçi bir bilgi ağı olan ve kitle kaynak şekilde yapılanmış olan Wikipedia, kişisel düşünce, deneyim ve bilgilerin paylaşıldığı bloglar; bireylerin eş, dost ve aile bireyleri gibi kimselerle kolaylıkla iletişime geçebildiği sosyal ağlar (Facebook, Twitter vb.) yeni medya olgusu web 2.0'ın bir sonucudur ve web 2.0 yalnızca kişiler arası ilişkiler ile bilgi ağını düzenlememekte, günümüzde politikacılar ve bloggerlardan, reklamcılara kadar birçok kimsenin faaliyet gösterdiği bir alanı ortaya koymaktadır (Carpenter ve Drezner, 2010: 257-258).

\subsection{Yeni Medya, Gündelik Yaşam ve Toplumsal Etkiler}


Yeni medya içinde şekillenen sosyal medya platformları günümüzde hayatın her noktasındadır. Kişilerarası ilişkilerden, kurumsal iletişime kadar artık birçok eylem sosyal medya aracılığı ile gerçekleştirilmektedir. Sawyer'a göre de (2011), sosyal medya gündelik yaşam ile birlikte günümüzün küresel toplumunun gittikçe popülerleşen bir parçası olmuştur. Gündelik rutinlerin önemli bir bileşeni olan sosyal medya, herkesin internet aracılığı ile kendisini ifade edebildiği bir alan olmuştur ve tek yönlü enformasyon ve iletişim akışı mühendisi olan geleneksel medyadan etkileşim boyutuyla kalın bir çizgi ile ayrilmaktadır (Sawyer, 2011).

2004 yılında Harvard öğrencisi Mark Zuckerberg tarafından başlatılan Facebook sosyal medyaya önemli bir soluk getirmiştir. Kullanım rahatlığ̀ "user-friendliness" Facebook'un en önemli özelliklerinden biri olarak öne çıkarken, bireyleri bir araya getirici bir yeni medya ortamı olması Facebook'un birçok toplum tarafindan benimsenmesine ve yoğun biçimde kullanılmasına da sebep olmuştur. Devamlı geliştirilen, yeni ikon ve uygulamalar eklenen Facebook, doğum günü, hatıralar, önemli günler hatırlatmaları ve kutlamaları ile "kişisel dijital bir arşiv" olmakla birlikte aynı zamanda anıların da arşivlendiği çevrimiçi bir platform niteliği taşımaktadır (GardeHansen, 2009: 141). Ahn'a göre de (2013), Facebook gibi sosyal medya platformları birçok insanın yaşamının ayrılmaz bir parçası olmuş durumdadır.

Yeni bir ilişkisel ve çevrimiçi kültür yaratan sosyal medya platformları, özellikle Facebook'un yoğun kullanımı ile çevrimiçi toplulukların yaratılmasını sağlamıştır. Bununla birlikte Facebook özel hayatın gizliliği bağlamında sıklıkla tartışmaların odak noktasında yer almaktadır. Aslında Facebook ve gizlilik olguları tartışılırken, liberal bir gizlilik kavramının ötesinde Facebook'un vatandaşların haklarının korunması ve güçlendirilmesi ile kurumsal gözetim noktasındaki faaliyetleri de doğru analiz edilmelidir (Fuchs, 2012: 140-141). Facebook gibi yoğun kullanılan bir sosyal paylaşım platformu da Twitter'dır ve özellikle sosyal medyanın gündeminin belirlenmesindeki rolü ile öne çıkmaktadır. 140 karakter ile düşünce ve paylaşımların ifade edildiği Twitter toplumsal sorunların tartışıldığı bir ortam olmakla birlikte, cereyan eden toplumsal olaylar sırasında bilgi akışının da hızlı ve etkileşimli biçimde sağlanması sebebiyle geleneksel medyaya bir anlamda savaş açan bir ortam olma özelliği de taşımaktadır. Örneğin 2013 yılında Türkiye'de gerçekleşen Gezi Parkı Eylemleri'nde Twitter hem geleneksel medyanın protesto edilmesi, hem de eyleme katılan kimselerin birbirleriyle haberleşmeleri ve yaşanan gelişmeleri sosyal ağlarda paylaşmaları ekseninde yoğun biçimde kullanılmıştır. (Kuyucu, 2015: 164). Bununla birlikte Arap Baharı ile büyük ivme kazanan sosyal medyanın her ülke ya da toplumda önemli bir rol oynayıp oynamadığı üzerine de düşünülmelidir (Aday, 2012: 6). Çünkü birçok Batı ülkesinde yaygın biçimde kullanılan Facebook, Twitter ve Youtube Çin ve İran'da yasaktır. Pakistan'da ise Youtube yasak konmuştur (Liebelson, 2014). Türkiye'de de Twitter ve Youtube'a geçtiğimiz yıllarda erişim yasağının getirildiği olmuş, fakat yasaklar kaldırılmıştır.

Sosyal medya ortamlarında sorun ya da konuları tartışmak, müzakere etmek olanağı bulan bireyler, aslında tüm takipçileri ya da arkadaşları ile iletişim kurma olanağına sahip değildir (Hampton vd., 2014). Zaten günümüzde de Twitter'ı tenzih ederek söylemek gerekirse, bireylerin herhangi bir sorunu tartışmak ya da görüşmekten ziyade, sosyal 
ağlarda takipçi sayısını artırmak ya da kendilerini göstermek gayelerine yöneldiği söylenebilir.

Wikipedia gibi işbirlikçi haber üretim girişimleri ya da açık artıma yoluyla internet üzerinden faaliyet gösteren eBay toplumun yeni medya bağlamındaki retorik üretimine olanak tanımaktadır (Turner, 2009: 77). Ayrıca bu çalışmada ele alınacak olan çevrimiçi hizmet satın alma pratiği de, yeni medyanın bir sonucu olarak gündelik yaşamda kendisini göstermektedir. Henüz çok yaygın olmasa da, bireyler bazı hizmetleri çevrimiçi hizmet satın alma sitelerinden alabilmektedir.

\subsection{Yeni Medyanın Gündelik Yaşama Etkileri Bağlamında armut.com ve evebirilazim.com Örnekleri ile Çevrimiçi Hizmet Satın Almanın İncelenmesi}

Yeni medya sayesinde bireyler gündelik yaşantılarında ihtiyaç duydukları birçok hizmeti çevrimiçi biçimde edinebilmektedir. Tematik internet siteleri aracıllğ 1 ile hizmet, ürün ya da eleman ile buluşabilen bireyler, kuşkusuz yeni medyanın sağladığı kolaylıklar sebebi ile bu pratiklere yönelmektedir.

$\mathrm{Bu}$ çalışmada da iletişim sürecindeki verilerin içeriğini incelemeyi amaçlayan ve tekrar edilebilirlik özelliğinin geçerlilik noktasında önemli olduğu düşünülen (Krippendorf, 2004) içerik analizi yöntemi ile armut.com ve evebirilazim.com internet sitelerinin çevrimiçi hizmeti nasıl sağladığı ve sunduğu incelenmiştir.

Örneklem olarak seçilen internet sitelerinde yapılan bireysel tarama ile elde edilen veriler, nitel ve nicel içerik analizi dâhilinde ele alınmıştır. Çalışmada, nitelikli bir inceleme yapabilmek için sitelerin sağladıkları hizmetler, hizmet sağladıkları yerler ve yapısallıkları anlamında birbirleri ile karşılaştırmaları da yapılmıştır.

\subsection{1. armut.com}

armut.com "Hizmet piş, ağzıma düş" sloganı ile yola çıkan çevrimiçi hizmet ve eleman satın almaya hizmet eden bir internet sitesidir. http://armut.com üzerinden çalışan armut.com kendisini; "armut'un genç, neşeli, müşterilerine âşık ve hizmet sektörüne memnuniyet devrimi getirmeye ant içmiş ekibi. Nezih, güzel senin benim gibi arkadaşlar hepsi." biçiminde nitelemektedir (armut.com, 2015).

Girişimcianne.com adlı şahsi blogda temelleri atılan armut.com, Başak Taşpınar Değim'in işinden ayrılıp kendine ait bir iş kurma düşüncesi ile ortaya çıkmıştır. Değim blogda armut.com'dan bahsetmiş, gelen yorumları da göz ederek armut'un oluşum evresindeki bilgileri siteyi takip eden kimseler ile paylaşmıştır. Değim aynı zamanda blogunda yurtdışı yaşam, doğum tecrübeleri ve girişimcilik konularında da yazılar paylaşmıştır. 16 kişilik profesyonel kadrosu ile çevrimiçi hizmet ve eleman temin eden armut.com, kurumun aynı zamanda CEO'su (İcra Kurulu Başkan) Başak Taşpınar Değim ve ürün sorumlusu Erol Değim tarafindan kurulmuştur (armut.com, 2015).

armut.com'da "http://armut.com/hesap/hizmetiste" uzantıs1 üzerinden talep ettiğiniz meslek ya da hizmeti, hizmeti nerede ve ne zaman, kaç saat talep ettiğiniz ile ne kadar bir bütçe öngördügünüzü yazmak sureti ile bir form doldurarak hizmet satın alma yolunda 
adımlar atılmaktadır. Cep telefonu ile e-posta adresinin de girildiği sistem üzerinden hizmet talebinde bulunulmaktadır. Eğer hizmet vermek istiyor iseniz; sisteme üye olup bir form doldurmanız gerekmektedir. 50.000 profesyonelin bulunduğu armut.com'da, ücretsiz teklif toplayıp karşılaştırılarak hangi hizmeti istediğinizi ya da kimi aradığınızı ana sayfada yer alan kısma yazarak (Örnek: boyacı arıyorum) ücretsiz teklif alabilmektesiniz (armut.com, 2015). Siteye e-posta adresinizle ya da Facebook hesabınızla ücretsiz üye olabilmekte ve ayda 30.000 müşterinin talep ilanı verdiği armut.com'da profil sayfası açabilmektesiniz (armut.com, 2015).

Türkiye'nin en kalabalık şehri olan İstanbul dişında 8 ilde daha hizmet veren ve ana sayfasında Facebook, Twitter, Pinterest ile Googleplus gibi önemli ve popüler platformlara uzantılar da veren armut.com sitesinde beyan ettiği üzere toplam 3 adımda şu şekilde çalışmaktadır: hizmet arıyorsanız eğer ilk adımda ihtiyacınız olan hizmeti yazıyor, birkaç soruya cevap veriyor ve e-posta adresinizi (gizli kalmaktadır) yazıyorsunuz. İkinci adımda ise armut.com iş ile ilgilenen profesyonellere ihtiyacınızı bildiriyor ve bu doğrultuda size birkaç saat içinde "1 ile 4 teklif” (teklife; fiyat tahmini, kişiye özel mesaj, iletişim bilgisi, fotoğraflı tanıtım profili ve daha önce tamamladı̆̆ işlerden kontrol edilmiş müşteri yorumları dâhildir.) geliyor. Üçüncü ve son adımda ise teklif veren profesyonellerin gerçek referans ve profil fotoğrafları ile ücretleri inceleyip bir karara varıyorsunuz. Bu bağlamda pazarlık şansı ile profesyonel ile mesaj ve telefon aracılığı ile ayrıntıları görüşme imkânı da buluyor ve hizmet verecek kimse ile anlaşıyor ya da anlaşma sağlayamıyorsunuz. Ayrıca eğer hizmet alırsanız, hizmetin sonrasında olumlu ya da olumsuz yorumlarda da bulunabiliyorsunuz (armut.com, 2015).

armut.com; İstanbul, Ankara, İzmir, Adana, Antalya, Bursa, Eskişehir, Kocaeli, Konya gibi 9 büyük şehirlerde; "Temizlik", "Tadilat", "Mobilya", "Nakliyat", "Tamir", "Fotoğraf", "Organizasyon”, “Özel ders” ve "Kişisel” olmak üzere toplam 9 genel başlık altındaki alanlarda hizmet vermektedir. armut.com'un ana sayfasında avantajlar anlamında "Müşteri Yorumları", "Rekabet Teklifi", "Uygun Fiyatlar" ve "Ücretsiz Kullanın" kısımları da bulunmaktadır (armut.com, 2015).

Tablo 1. armut.com'un Hizmet Sağladığı İller ve Genel Hizmet Alanları

\begin{tabular}{lr}
\hline İl & Hizmet Sağlanan Alanlar \\
\hline İstanbul & \\
Ankara & \\
İzmir & \\
Adana & Temizlik, Tadilat, Mobilya, Nakliyat, Tamir, Fotoğraf, \\
Antalya & Organizasyon, Özel Ders, Kişisel \\
Bursa & \\
Eskişehir & \\
Kocaeli & \\
Konya & \\
\hline
\end{tabular}

armut.com'un şehirler bazında hizmet sağladığı alanlar ve hizmet sağladığ1 ilçeler aşağıdaki tablolarda listelenmiştir. armut.com, illerde fazla sayıda ilçede hizmet sağladığından her bir il için ayrı bir tablo hazırlanmıştır. armut.com İstanbul'da toplam 39 ilçede hizmet sağlamaktadır. Söz konusu tablo aşağıdaki gibidir: 
Tablo 2. armut.com'un İstanbul'da Hizmet Sağladığı İlçeler ve Hizmet Sağlanan Alanlar

\begin{tabular}{|c|c|}
\hline Hizmet Sağlanan İlçeler & Hizmet Sağlanan Alanlar \\
\hline Adalar & 3D Teknik Çizim Modelleme Tasarım, Duvar Kâğıdı \\
\hline Arnavutköy & Döşeme, Klima Servisi Montaj Bakım Arıza, Alarm \\
\hline Ataşehir & Güvenlik Kamera, Duvar Ustası, Koltuk Döşeme, \\
\hline Avcilar & Kaplama, Yenileme, Alçı Ustası, Elektrik Tesisat \\
\hline Bağcılar & Tamir Montaj (Elektrikçi), Kombi Servisi (Arıza ve \\
\hline Bahçelievler & Bakım), Alçıpan Asma Tavan, Eşya Depolama, \\
\hline Bakırköy & Köpek Eğitimi, Anahtar Teslim İnşaat, Ev Tadilat, \\
\hline Başakşehir & Logo Tasarımı, Anahtar Teslim Tadilat Dekorasyon, \\
\hline Bayrampaşa & Ev Temizliği, Marangoz, Android Uygulama \\
\hline Beşiktaş & Geliştirme, Ev Yaptırma \\
\hline Beykoz & Boyama, Lake ve Cila, Asansörlü Nakliyat, Evden \\
\hline Beylikdüzü & Eve Nakliyat, Mutfak Tadilat, Banyo Tadilat, Fayans \\
\hline Beyoğlu & Seramik Döşeme, Ofis Temizliği, Bebek Doğum \\
\hline Büyükçekmece & Fotoğrafçıs1, Fotoğrafçı, Özel Dedektif, Bilgisayar ve \\
\hline Çatalca & Laptop Tamiri, Freelance Grafiker Grafik Tasarım, \\
\hline Çekmeköy & Özel Mobilya Yapımı, Bina ve Apartman Temizliği, \\
\hline Esenler & Freelance Programcı/ Yazılımcı, Parça Eşya Taşıma, \\
\hline Esenyurt & Boyacı (Boya Badana Ustası), Halı Y1kama \\
\hline Eyüp & Temizleme, Parke Laminat Döşeme, Butik Pasta ve \\
\hline Fatih & Kurabiye, Haşere İlaçlama, Psikolog, \\
\hline Gaziosmanpaşa & Yalıtımı/İzolasyonu, Havuz Yapımı, PVC Pencere \\
\hline Güngören & Kapı Plastik Doğrama, Çatı Yapımı ve Tadilatı, Hazır \\
\hline Kadiköy & Mutfak, Şehir İçi Nakliyat, Demir Doğrama ve \\
\hline Kâğıthane & Ferforje, İç Mimar ve Dekorasyon, Şehirler Arası \\
\hline Kartal & Nakliyat, D1ş Çekim Fotoğraf, İnşaat Sonrası \\
\hline Küçükçekmece & Temizlik, Su Tesisatçısı/Sıhhi Tesisat, Dış Cephe \\
\hline Maltepe & Boyama, iPhone iPad Uygulama Geliştirme, $\mathrm{Su}$ \\
\hline Pendik & Yalıtımı/İzolasyonu, Dış Cephe Kaplama/Giydirme, \\
\hline Sancaktepe & Isı Yalıtım1/ İzolasyonu, Tadilat Dekorasyon, Dış \\
\hline Sariyer & Cephe Mantolama, Kalorifer ve Doğalgaz Tesisatı, \\
\hline Şile, Silivri, Şişli & Teknede Düğün ve Nişan, Doğum \\
\hline Sultanbeyli & Organizasyonu, Kap1 Pencere Montaj ve Tamiri, \\
\hline Sultangazi & Teras Kapama, Düğün Fotoğrafçısı, Katlanır Cam \\
\hline Tuzla & Balkon, Ürün ve Katalog, Fotoğraf Çekimi, Dügün \\
\hline Ümraniye & Organizasyon, Kına Organizasyon, Web Tasarım ve \\
\hline Üsküdar & Programlama \\
\hline Zeytil & \\
\hline
\end{tabular}

Toplam 9 farklı ilde hizmet veren armut.com, Ankara'da da toplam 14 ilçede hizmet sağlamaktadır. Söz konusu hizmetler ve ilçeler aşağıdaki tabloda listelenmiştir: 
Tablo 3. armut.com'un Ankara'da Hizmet Sağladığı İlçeler ve Hizmet Sağlanan Alanlar

\begin{tabular}{|c|c|}
\hline Hizmet Sağlanan İlçeler & Hizmet Sağlanan Alanlar \\
\hline Akyurt & 3D Teknik Çizim Modelleme Tasarım, Duvar Kağıdı \\
\hline Altındağ & Döşeme, Klima Servisi Montaj Bakım Arıza, Alarm \\
\hline Çankaya & Güvenlik Kamera, Duvar Ustası, Koltuk Döșeme, \\
\hline Çubuk & Kaplama, Yenileme, Alçı Ustası, Elektrik Tesisat \\
\hline Elmadağ & Tamir Montaj (Elektrikçi), Kombi Servisi (Arıza ve \\
\hline Etimesgut & Bakım), Alçıpan Asma Tavan, Eşya Depolama, Köpek \\
\hline Gölbaşı & Eğitimi, Anahtar Teslim İnşaat, Ev Tadilat, Logo \\
\hline Kazan & Tasarım1, Anahtar Teslim Tadilat Dekorasyon, Ev \\
\hline Keçiören & Temizliği, Marangoz, Android Uygulama Geliștirme, \\
\hline Mamak & Ev Yaptırma Müteahhit, Mobilya Boyama, Lake ve \\
\hline Polatl1 & Cila, Asansörlü Nakliyat, Evden Eve Nakliyat, Mutfak \\
\hline Pursaklar & Tadilat, Banyo Tadilat, Fayans Seramik Döşeme, Ofis \\
\hline Sincan & Temizlĭği, Bebek Doğum Fotoğrafçısı, Fotoğrafçı, \\
\hline Yenimahalle & Özel Dedektif, Bilgisayar ve Laptop Tamiri, Freelance \\
\hline & Grafiker Grafik Tasarım, Özel Mobilya Yapımı, Bina \\
\hline & Freelance \\
\hline & $\begin{array}{l}\text { Programc1/Yazılımc1, Parça Eşya Taşıma, Boyacı } \\
\text { (Boya Badana Ustası), Halı Yıkama Temizleme, Parke }\end{array}$ \\
\hline & Laminat Döşeme, Butik Pasta ve Kurabiye, Haşere \\
\hline & İlaçlama, Psikolog, Çatı Yalıtımı/ İzolasyonu, Havuz \\
\hline & Yapımı, PVC Pencere Kapı Plastik Doğrama, Çatı \\
\hline & Yapımı ve Tadilatı, Hazır Mutfak, Şehir İçi Nakliyat, \\
\hline & Demir Doğrama ve Ferforje, İç Mimar ve Dekorasyon, \\
\hline & Şehirler Arası Nakliyat, Dış Çekim Fotoğraf, İnşaat \\
\hline & Sonrası Temizlik, Su Tesisatçısı/Sıhhi Tesisat, Dış \\
\hline & Cephe Boyama, iPhone iPad Uygulama Geliştirme, Su \\
\hline & $\begin{array}{l}\text { Yalıtımı İzolasyonu, Diş Cephe Kaplama/Giydirme, } \\
\text { Is1 Yalıtımı/Izolasyonu, Tadilat Dekorasyon, Dis }\end{array}$ \\
\hline & Cephe Mantolama, Kalorifer ve Doğalgaz Tesisatı, \\
\hline & Teras Kapama, Doğum Günü Organizasyonu, Kap1 \\
\hline & Pencere Montaj ve Tamiri, Ürün ve Katalog Fotoğraf \\
\hline & $\begin{array}{l}\text { Çekimi, Düğün Fotoğrafçısı, Katlanır Cam Balkon, } \\
\text { Web Tasarım ve Programlama }\end{array}$ \\
\hline
\end{tabular}

Hizmet arayan kimselerin verdikleri ilanlardan örneklerin de yer aldığı armut.com, aşağıdaki tabloda da belirtildiği üzere İzmir'de de toplam 20 ilçede hizmet sağlamaktadır. 
Tablo 4. armut.com'un İzmir'de Hizmet Sağladığı İlçeler ve Hizmet Sağlanan Alanlar

\begin{tabular}{|c|c|}
\hline Hizmet Sağlanan İlçeler & Hizmet Sağlanan Alanlar \\
\hline Aliağa & 3D Teknik Çizim Modelleme Tasarım, Duvar Kâğıdı \\
\hline Balçova & Döşeme, Klima Servisi Montaj Bakım Arıza, Alarm \\
\hline Bayraklı & Güvenlik Kamera, Duvar Ustası, Koltuk Döşeme, \\
\hline Bornova & Kaplama, Yenileme, Alçı Ustası, Elektrik Tesisat Tamir \\
\hline Buca & Montaj (Elektrikçi), Kombi Servisi (Arıza ve Bakım), \\
\hline Çeşme & Alçipan Asma Tavan, Eşya Depolama, Köpek Eğitimi, \\
\hline Çiğli & Anahtar Teslim İnşaat, Ev Tadilat Logo Tasarımı, \\
\hline Cumaovas1 (Menderes) & Anahtar Teslim Tadilat Dekorasyon, Ev Temizliği, \\
\hline Foça & Marangoz, Android Uygulama Geliştirme, Ev Yaptırma \\
\hline Gaziemir & Müteahhit, Mobilya Boyama, Lake ve Cila, Asansörlü \\
\hline Güzelbahçe & Nakliyat, Evden Eve Nakliyat, Mutfak Tadilat, Banyo \\
\hline Karabağlar & Tadilat, Fayans Seramik Döşeme, Ofis Temizliği, Bebek \\
\hline Karşıyaka & Doğum Fotoğrafçıs1, Fotoğrafçı, Özel Dedektif, \\
\hline Kemalpaşa & Bilgisayar ve Laptop Tamiri, Freelance Grafiker Grafik \\
\hline Konak & Tasarım, Özel Mobilya Yapımı, Bina ve Apartman \\
\hline Menemen & Temizliği, Freelance Programcı/Yazılımcı, Parça Eşya \\
\hline Narlıdere & Taşıma, Boyacı (Boya Badana Ustası), Halı Yıkama \\
\hline Seferihisar & Temizleme, Parke Laminat Döşeme, Butik Pasta ve \\
\hline Torbalı & Kurabiye, Haşere İlaçlama, Psikolog, Çatı Yalıtımı / \\
\hline \multirow{14}{*}{ Urla } & İzolasyonu, Havuz Yapımı, PVC Pencere Kap1 Plastik \\
\hline & Doğrama, Çatı Yapımı ve Tadilatı, Hazır Mutfak, Şehir \\
\hline & İçi Nakliyat, Demir Doğrama ve Ferforje, İç Mimar ve \\
\hline & Dekorasyon, Şehirler Arası Nakliyat, Dış Çekim \\
\hline & Fotoğraf, İnşaat Sonrası Temizlik, Su Tesisatçısı/Sıhhi \\
\hline & Tesisat, Dış Cephe Boyama, iPhone iPad Uygulama \\
\hline & Geliştirme, Su Yalıtımı /İzolasyonu, Dış Cephe \\
\hline & Kaplama/Giydirme, Is1 Yalıtımı/ İzolasyonu, Tadilat \\
\hline & Dekorasyon, Dış Cephe Mantolama, Kalorifer ve \\
\hline & Doğalgaz Tesisat1, Teknede Düğün ve Nişan, Doğum \\
\hline & Günü Organizasyonu, Kapı Pencere Montaj ve Tamiri, \\
\hline & Teras Kapama, Düğün Fotoğrafçısı, Katlanır Cam \\
\hline & Balkon, Ürün ve Katalog Fotoğraf Çekimi, Düğün \\
\hline & $\begin{array}{l}\text { Organizasyon, Kına Organizasyon, Web Tasarım ve } \\
\text { Programlama }\end{array}$ \\
\hline
\end{tabular}

armut.com'da kullanıcılardan gelen yorumlara da "En İyi Müşteri Yorumları" başlığı ile yer verilmektedir. Yorumlardan bazı örnekler aşă̆ıdaki gibidir:

Yazan: Oğuz Yılmaz

Boyacl (Boya Badana Ustasl) 29/05/2015

"Cevdet Usta işe zamanında başladl. Öngördügü tarihte de bitirdi. Peşinde koşturan, geleceğim deyip gelmeyen ustalardan değil, aldı̆̆ parayı da hak ediyor. İşine özeniyor. Benzer bir işim olduğunda da kendisini tekrar çağırabilirim." 
"Emekli ögretmenim, çok gergin olarak gittik. Kendisinin samimi ve içten tavrı bizi çok etkiledi. Kubilay beyden çok memnun kaldlk. Herkese tavsiye ediyorum. Ylldı olarak da 10 üzerinden 10 veriyoruz."

Adana'da toplam 4 ilçede hizmet sağlayan armut.com'un söz konusu ilde sağladığı hizmetler ve hizmet sağlanan ilçeler aşağıda listelenmiştir:

Tablo 5. armut.com'un Adana'da Hizmet Sağladığı İlçeler ve Hizmet Sağlanan Alanlar

\begin{tabular}{|c|c|}
\hline Hizmet Sağlanan İlçeler & Hizmet Sağlanan Alanlar \\
\hline $\begin{array}{l}\text { Çukurova } \\
\text { Sarıçam } \\
\text { Seyhan } \\
\text { Yüreğir }\end{array}$ & 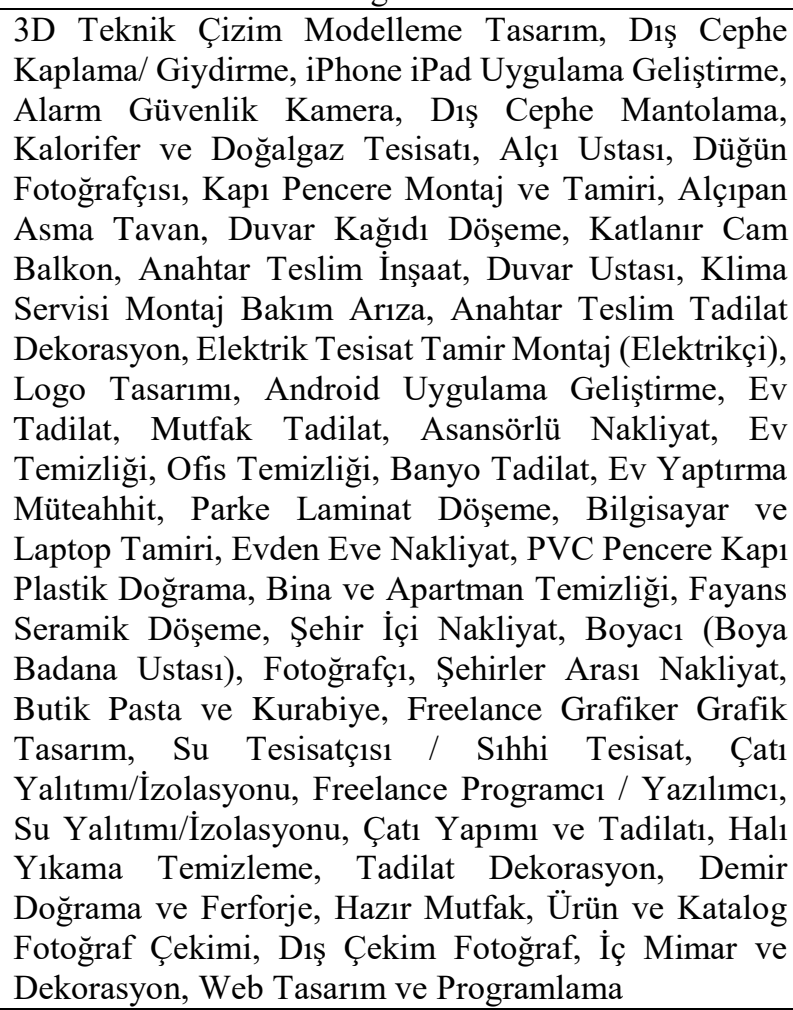 \\
\hline
\end{tabular}

armut.com Antalya'da da toplam 9 ilçede aşağıdaki tabloda ifade edilen hizmetleri sağlamaktadır: 
Tablo 6. armut.com'un Antalya'da Hizmet Sağladığı İlçeler ve Hizmet Sağlanan Alanlar

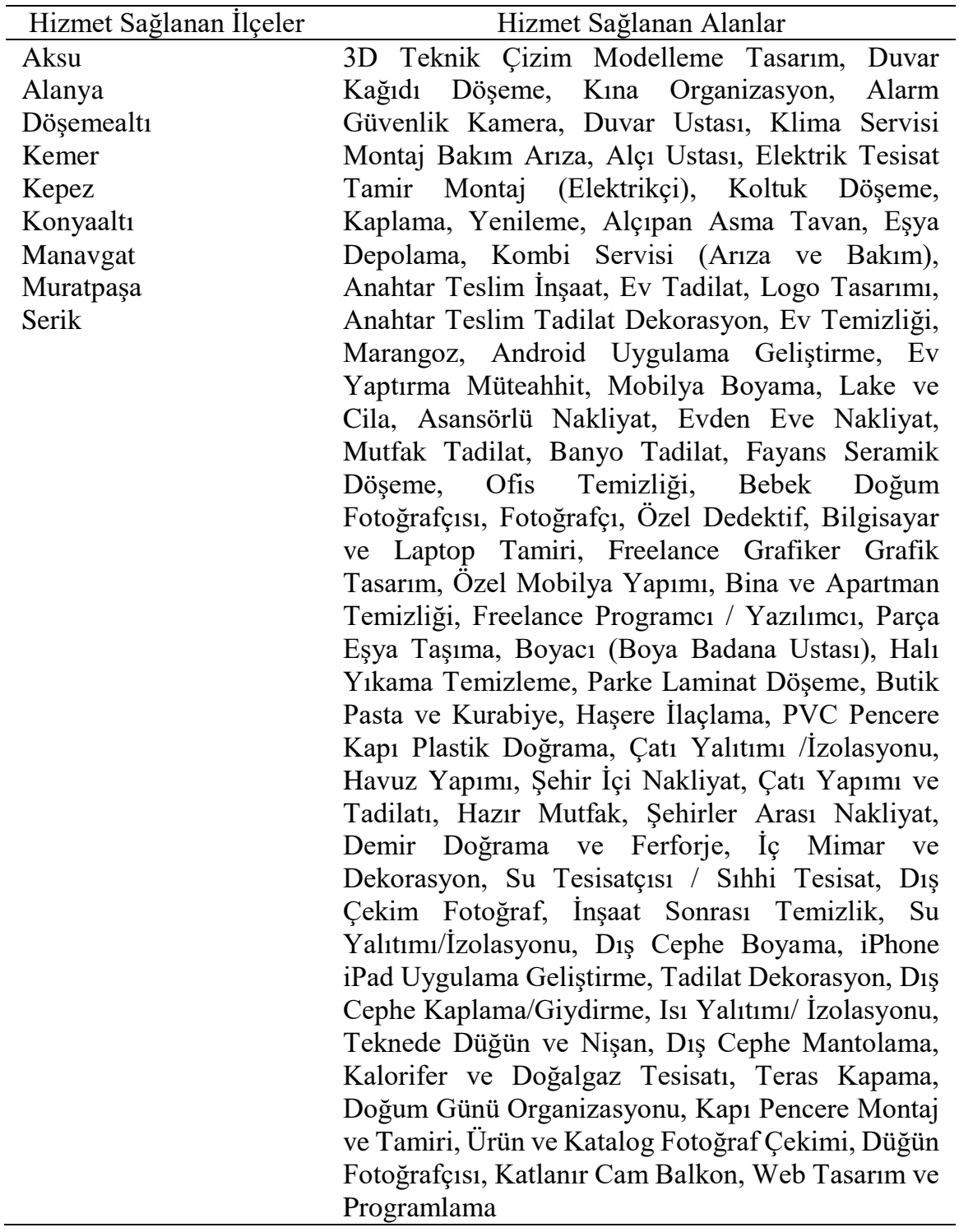

Bursa'da ise tıpkı Antalya'daki gibi toplam 9 ilçede sağlanan hizmetler ise aşağıdaki tablodaki gibidir: 
Tablo 7. armut.com'un Bursa'da Hizmet Sağladığı İlçeler ve Hizmet Sağlanan Alanlar

\begin{tabular}{|c|c|}
\hline Hizmet Sağlanan İlçeler & Hizmet Sağlanan Alanlar \\
\hline $\begin{array}{l}\text { Gemlik } \\
\text { Gürsu } \\
\text { İnegöl } \\
\text { Ketsel } \\
\text { Mudanya } \\
\text { Nilüfer } \\
\text { Orhangazi } \\
\text { Osmangazi } \\
\text { Yıldırım }\end{array}$ & 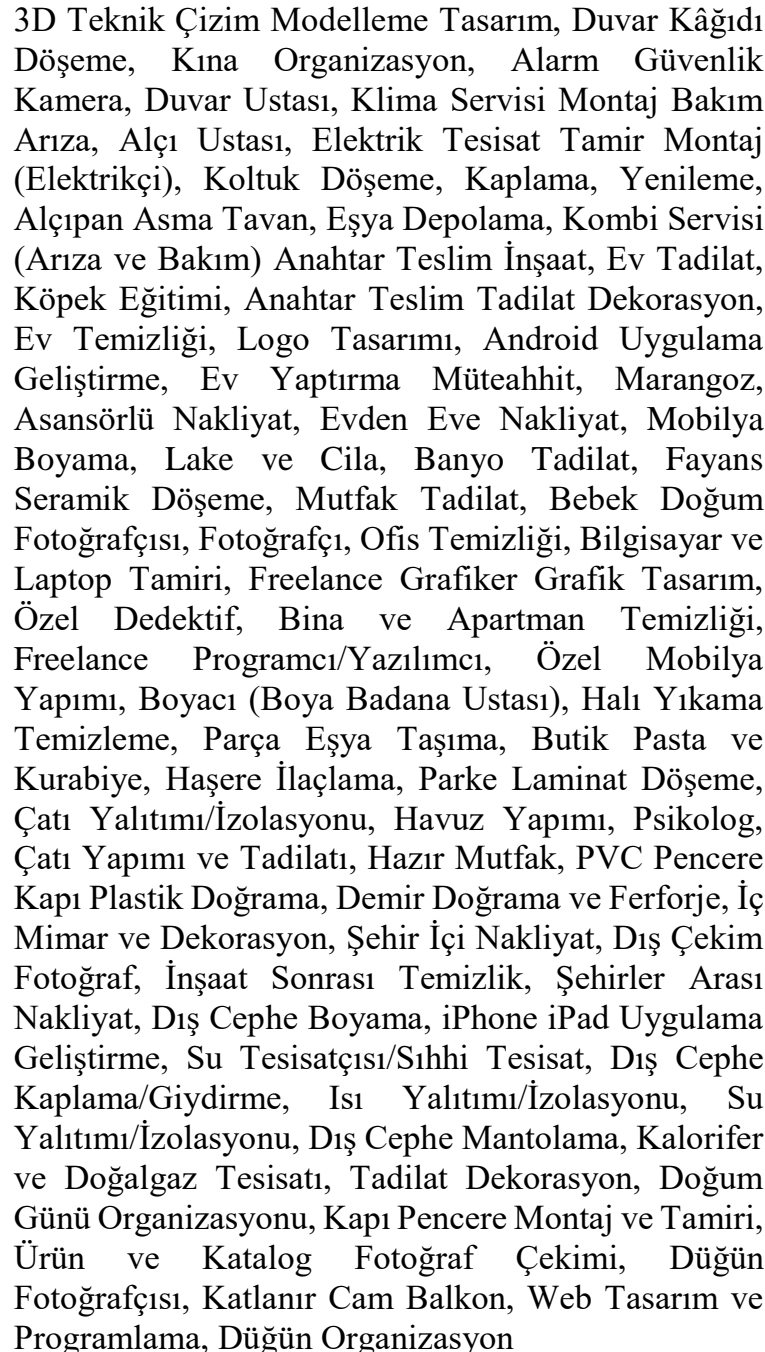 \\
\hline
\end{tabular}

armut.com Eskişehir'de ise yalnızca 2 ilçede hizmet vermektedir. Bu ilçeler olan Odunpazarı ve Tepebaşı'nda sağlanan hizmetler şöyledir: 
Tablo 8. armut.com'un Eskişehir'de Hizmet Sağladığı İlçeler ve Hizmet Sağlanan Alanlar

\begin{tabular}{ll}
\hline Hizmet Sağlanan İlçeler & Hizmet Sağlanan Alanlar \\
\hline Odunpazarı & 3D Teknik Çizim Modelleme Tasarım, Dış Cephe \\
Tepebaşı & Boyama, İç Mimar ve Dekorasyon, Alarm Güvenlik \\
& Kamera, Dış Cephe Kaplama/Giydirme, İnşaat \\
& Sonrası Temizlik, Alçı Ustası, Dış Cephe \\
& Mantolama, Isı Yalıtımı/İzolasyonu, Alçıpan Asma \\
& Tavan, Doğum Günü Organizasyonu, Kalorifer ve \\
& Doğalgaz Tesisatı, Anahtar Teslim İnşaat, Düğün \\
& Fotoğrafçısı, Koltuk Döşeme, Kaplama, Yenileme, \\
& Anahtar Teslim Tadilat Dekorasyon, Düğün \\
& Organizasyon, Logo Tasarımı, Android Uygulama \\
& Geliştirme, Elektrik Tesisat Tamir Montaj \\
& (Elektrikçi), Ofis Temizliği, Asansörlü Nakliyat, Ev \\
Tadilat, Özel Mobilya Yapımı, Banyo Tadilat, Ev & Temizliği, Psikolog, Bebek Doğum Fotoğrafçısı, Ev \\
& Yaptırma Müteahhit, Şehir İçi Nakliyat, Bilgisayar \\
& ve Laptop Tamiri, Evden Eve Nakliyat, Şehirler \\
Arası Nakliyat, Bina ve Apartman Temizliği, Fayans \\
Seramik Döşeme, Su Tesisatçısı/Sıhhi Tesisat, \\
Boyacı (Boya Badana Ustası, Fotoğrafçı, Su \\
Yalıtımı/İzolasyonu, Butik Pasta ve Kurabiye, \\
Freelance Grafiker Grafik Tasarım, Tadilat \\
Dekorasyon, Çatı Yalıtımı/İzolasyonu, Freelance \\
Programcı/Yazılımcı, Ürün ve Katalog Fotoğraf \\
Çekimi, Dış Çekim Fotoğraf, Halı Yıkama \\
Temizleme, Web Tasarım ve Programlama \\
\hline
\end{tabular}

armut.com tarafından Kocaeli'nde de hizmet sağlanmaktadır. Toplam 10 ilçede sağlanan hizmetler ve hizmet sunulan ilçeler de şu şekildedir:

Tablo 9. armut.com'un Kocaeli’nde Hizmet Sağladığı İlçeler ve Hizmet Sağlanan Alanlar

\begin{tabular}{ll}
\hline Hizmet Sağlanan İlçeler & \multicolumn{1}{c}{ Hizmet Sağlanan Alanlar } \\
\hline Başiskele & 3D Teknik Çizim Modelleme Tasarım, Düğün \\
Çayırova & Organizasyon, Kına Organizasyon, Alarm Güvenlik \\
Darıca & Kamera, Duvar Kâğıdı Döşeme, Klima Servisi \\
Derince & Montaj Bakım Arıza, Alçı Ustası, Duvar Ustası, \\
Gebze & Koltuk Döşeme, Kaplama, Yenileme, Alçıpan Asma \\
Gölcük & Tavan, Elektrik Tesisat Tamir Montaj (Elektrikçi), \\
İzmit & Kombi Servisi (Arıza ve Bakım), Anahtar Teslim \\
Karamürsel & İşaat, Eşya Depolama, Logo Tasarımı, Anahtar \\
Kartepe & Teslim Tadilat Dekorasyon, Ev Tadilat, Marangoz, \\
Tütünçiftlik & Android Uygulama Geliştirme, Ev Temizliği, \\
& Mutfak Tadilat, Banyo Tadilat, Ev Yaptırma \\
\hline
\end{tabular}




Müteahhit, Ofis Temizliği, Bebek Doğum
Fotoğrafçısı, Evden Eve Nakliyat, Özel Dedektif,
Bilgisayar ve Laptop Tamiri, Fayans Seramik
Döşeme, Özel Mobilya Yapımı, Bina ve Apartman
Temizliği, Fotoğrafçı, Parça, Eşya Taşıma, Boyacı
(Boya Badana Ustası), Freelance Grafiker Grafik
Tasarım, Parke Laminat Döşeme, Butik Pasta ve
Kurabiye, Freelance Programc1/Yazılımcı, Psikolog,
Çatı Yalıtımı/İzolasyonu, Halı Yıama Temizleme,
PVC Pencere Kapı Plastik Doğrama, Çatı Yapımı ve
Tadilatı, Hazır Mutfak, Şehir İçi Nakliyat, Demir
Doğrama ve Ferforje, İç Mimar ve Dekorasyon,
Şehirler Arası Nakliyat, Dış Çekim Fotoğraf, İņaat
Sonrası Temizlik, Su Tesisatçısı/Sıhhi Tesisat, Dış
Cephe Boyama, Isı Yalıtımı/İzolasyonu, Su
Yalıtımı/İzolasyonu, Dış Cephe Kaplama/Giydirme,
Kalorifer ve Doğalgaz Tesisatı, Tadilat Dekorasyon,
Dış Cephe, Mantolama, Kapı Pencere Montaj ve
Tamiri, Ürün ve Katalog Fotoğraf Çekimi, Düğün
Fotoğrafçısı, Katlanır Cam Balkon, Web Tasarım ve
Programlama

Konya'da armut.com tarafindan toplam 3 ilçede sağlanan hizmetler ve hizmet sağlanan söz konusu ilçeler aşağıdaki tabloda verilmiştir:

Tablo 10. armut.com’un Konya’da Hizmet Sağladığg İlçeler ve Hizmet Sağlanan Alanlar

\begin{tabular}{ll}
\hline Hizmet Sağlanan İlçeler & \multicolumn{1}{c}{ Hizmet Sağlanan Alanlar } \\
\hline Karatay & 3D Teknik Çizim Modelleme Tasarım, Duvar \\
Meram & Kâğı̆ı̈ Döşeme, Klima Servisi Montaj Bakım Arıza, \\
& Alarm Güvenlik Kamera, Duvar Ustası, Kombi \\
& Servisi (Arıza ve Bakım), Alçı Ustası, Elektrik \\
& Tesisat Tamir Montaj (Elektrikçi), Logo Tasarımı, \\
& Alçıpan Asma Tavan, Eşya Depolama, Marangoz, \\
& Anahtar Teslim İnşaat, Ev Tadilat, Mutfak Tadilat, \\
& Anahtar Teslim Tadilat Dekorasyon, Ev Temizliği, \\
& Ofis Temizliği, Asansörlü Nakliyat, Ev Yaptırma \\
& Müteahhit, Özel Mobilya Yapımı, Bebek Doğum \\
& Fotoğrafçısı, Evden Eve Nakliyat, Parça Eşya \\
& Taşıma, Bilgisayar ve Laptop Tamiri, Fayans \\
& Seramik Döşeme, Parke Laminat Döşeme, Bina ve \\
& Apartman Temizliği, Fotoğrafçı, Psikolog, Boyacı \\
& (Boya Badana Ustası), Freelance Grafiker Grafik \\
& Tasarım, PVC Pencere Kapı Plastik Doğrama, Çatı \\
& Yalıtımı/İzolasyonu, \\
& Programcı/Yazılımcı, Şehir İçi Nakliyat, Çatı \\
\hline
\end{tabular}


Yapımı ve Tadilatı, Halı Yıkama Temizleme, Şehirler Arası Nakliyat, Demir Doğrama ve Ferforje, Haşere İlaçlama, Su Tesisatçısı/Sıhhi Tesisat, Dış Çekim Fotoğraf, İç Mimar ve Dekorasyon, Su Yalıtımı/İzolasyonu, Dış Cephe Boyama, İnşaat Sonrası Temizlik, Tadilat Dekorasyon, Dış Cephe Kaplama/Giydirme, Isı Yalıtımı/İzolasyonu, Ürün ve Katalog Fotoğraf Çekimi, Dış Cephe Mantolama, Kalorifer ve Doğalgaz Tesisatı, Web Tasarım ve Programlama, Düğün Fotoğrafçıs1

armut.com'da ayrıca hizmet sunulan ilçelerde sunulan hizmetler de detaylı olarak verilmiştir. Fakat niceliksel fazlalıkları nedeniyle çalışma kapsamında ilçeler bazında sağlanan hizmetler incelenmemiştir. Zaten söz konusu hizmetler ilçelerde sağlanan hizmetlerden birçoğunu nitelediğinden, çalışmayı bu şekilde sınırlamak uygun görülmüştür.

\subsection{2. evebirilazim.com}

Çalışmada incelenen bir diğer çevrimiçi hizmet sağlama sitesi olan evebirilazim.com da, armut.com gibi bireylere çevrimiçi hizmet temini yapmaktadır. armut.com'dan farklı olarak yalnızca temizlik alanında çalışan evebirilazim.com, tematik bir çevrimiçi hizmet satın alma sitesi olarak konumlandırılmaktadır. "https://www.evebirilazim.com/” adresi üzerinden çalışan site, Boğaziçi Üniversitesi mezunu Veysel Berk tarafindan kurulmuştur. İş Geliştirmeden Sorumlu Başkan Yardımcılığı'nı Tolga Tunç Değer'in, Operasyon Müdürlügü̈nü ise Ülgen Arslan'ın yaptığı evebirilazim.com'ın 4 kişilik çekirdek kadrosundaki son isim ise Murat Düzgün (evebirilazim.com, 2015).

Siteye girildiğine ilkin "Kayıt Ol” ve "Giriş Yap" yönlendirmelerinin bulunduğu ana sayfada; "Size en yakın referanslı temizlikçileri bulun!" sloganı ile "63 TL'den başlayan fiyatlar", "Hemen rezervasyon yapın", "Evinize gelsin", "Kredi kartı ile ödeyin" ve "\%100 Memnuniyet Garantisi" kısımları ile "Temizlikçi Bul” ve Temizlikçi Ol” ile "Hakkımızda", "Yorumlar", "Basında Biz", "Sorular" ve "Kariyer" kısımları yer almaktadır. Facebook beğeni uzantısının da bulunduğu ana sayfada; Basında biz başlığını niteleyen ve evebirilazim.com ile kurucusu Veysel Berk'i konu alan yazılı ve görsel medya haberlerine de yer verilmektedir. "Eve Biri Lazım! - Mutlu ve Temiz Evler" ifadesini kullanan evebirilazim.com ana sayfada Facebook ve Twitter uzantıları verirken, iletişim bilgilerini; bilgi@evebirilazim.com şeklindeki e-posta adresi ve 09:00 ile 18:00 saatleri arasinda hizmet veren 054432534 41, 05443253442 ve 05443253443 Gsm numaraları ile belirtmektedir (evebirilazim.com, 2015). Siteden temizlik elemanı ve temizlik hizmeti talep eden kimseler evebirilazim.com ile ilgili yorumlarda bulunmakta ve bu yorumlar sitede yer almaktadır. Sitede temizlik yaptıran kimselerden gelen yorumlardan bazıları şöyledir (evebirilazim.com, 2015):

Yazan: Zehra K. İstanbul / Beşiktaş 
"Profesyonel ve müşteri memnuniyetini göz önünde bulunduran yaklaşımınız için tebrikler. Türkiye de açık olan bir boşluğu doldurduğu inancındayım, să̆ladığı bu servis ile..."

Yazan: Dilek O. İstanbul/Beşiktaş

"Eve biri lazım dedim geldiler. Kapıyı açtım güler yüzlü, nazik Ümran hanım karşımdaydı. Müşteri memnuniyetini ön planda tutuklarını ve işlerine olan sayglarını ispatladilar..."

evebirilazim.com'da temizlik hizmeti sağlama 3 adımda yapılmaktadır. İlk adımda; rezervasyon yapılmakta, ikinci adımda ev temizlenmekte, üçüncü adımda ise temiz evin keyfini sürme vaadinde bulunulmaktadır. Sitede yer alan Temizlikçi ol kısmında; "Hemen başla, ayda 2400 TL kazan" ve "Ne zaman çalışacağını sen belirle!" sloganları altında yer alan bir form doldurulmaktadır. Formda ad soy ad, e-posta adresi, telefon numarası, ilçe, daha önce ev temizliğine çalışılıp çalışılmadığı ile belirtilmek istenen not gibi bilgiler istenmektedir. Türkiye İş Kurumu ve Haber Türk destekli olduğu ifade edilen sitede söz konusu form doldurulduktan sonra başvurup tamamlanmakta ve temizlik hizmeti vermek isteyen kimse evebirilazim.com tarafından aranmaktadır. $\mathrm{Bu}$ kısımda hangi şartlarda çalışılacağı kapsamında çalışma gün ve saatlerini belirleme opsiyonel olarak temizlik hizmeti vermek isteyen kimseye bırakılmaktadır. Sitede verilecek hizmetten kazanılacak ücretin ise her saat için alınacağı ve aylık 4000 TL'ye kadar gelir sağlanabileceği de vurgulanmaktadır. Bununla birlikte alınacak bahşişlerin ise temizlik hizmeti sağlanan kişinin kendisine kalacağı ifade edilmektedir. evebirilazim.com'un kurucusu Veysel Berk ayrıca sitede hemen geri döneceği beyanı ile "Hakkımızda" kısmında veysel@evebirilazim.com şeklindeki e-posta adresini de vermektedir (evebirilazim.com, 2015).

Henüz yalnızca İstanbul'da hizmet sağlayan ve yakında tüm illerde hizmet vereceğini ifade eden ve ad soyad, e-posta adresi, telefon ve şifre ile kayıt olunan evebirilazim.com'un sorular kısmında hizmet süresinin evin büyüklüğü ile talep edilen hizmetin biçimine göre değiştiği de ifade edilmektedir. Bu kısımda daha önce hizmet alınmış olan bir temizlik hizmeti verenin tekrar çağırılabileceği, ödemelerin "Kredi Kartı" ya da "Paypal" aracılığı ile yapılabildiği, temizlik hizmetinin çevrimiçi olarak satın alınıp sevilen bir kimseye hediye edilebileceği, aynı gün için müsait temizlikçi çağrılabileceği, temizlik hizmeti verecek kişiyi hafta sonu da çağırabileceğiniz ve uygun görülen zaman diliminde çağırabileceğiniz gibi detaylar verilmektedir. Temizlik hizmeti verecek olan kişi temizlik hizmeti isteyen kimsenin evinde mevcut olan temizlik malzemelerini kullanmaktadır. Fakat site yakın zamanda evebirilazim.com'dan temizlik malzemesi de talep edilebileceğini ifade etmektedir (evebirilazim.com, 2015).

evebirilazim.com'da temizlik hizmeti almak adına rezervasyon yapılmaktadır. 4 adımda gerçekleşen rezervasyonda ilkin evin büyüklüğü ve temizlik ihtiyacına ilişkin ayrıntılar seçilmektedir. Toplam 4 ayrı temizlik paketi bulunan evebirilazim.com'da en ucuz paket 75 TL, en pahalı paket ise 135 TL'dir. Paketler, evin büyüklüğüne göre farklılık göstermektedir (Tablo 11). 
Tablo 11. evebirilazim.com'un Paket Bazında Sağladığı Hizmetler

\begin{tabular}{|c|c|c|}
\hline Ev Büyüklüğü & Paket Fiyatı (TL) & Pakete Dâhil Olan Hizmetler \\
\hline & & $\begin{array}{l}\text { Yerleri süpürme, yerleri silme, toz alma, } \\
\text { kapllar mutfak ve banvo temizliŏi tezoâh }\end{array}$ \\
\hline $1+1$ & 75 & $\begin{array}{l}\text { üzerleri ve dolap kapakları, aynalar, } \\
\text { lavabolar, klozet, küvet. }\end{array}$ \\
\hline $2+1$ & 90 & $\begin{array}{l}\text { Yerleri süpürme, yerleri silme, toz alma, } \\
\text { kapılar, mutfak ve banyo temizliği, tezgâh } \\
\text { üzerleri ve dolap kapakları, aynalar, } \\
\text { lavabolar, klozet, küvet. }\end{array}$ \\
\hline $3+1$ & 105 & $\begin{array}{l}\text { Yerleri süpürme, yerleri silme, toz alma, } \\
\text { kapilar, mutfak ve banyo temizliği, tezgâh } \\
\text { üzerleri ve dolap kapakları, aynalar, } \\
\text { lavabolar, klozet, küvet. }\end{array}$ \\
\hline $4+1$ & 135 & $\begin{array}{l}\text { Yerleri süpürme, yerleri silme, toz alma, } \\
\text { kapılar, mutfak ve banyo temizliği, tezgâh } \\
\text { üzerleri ve dolap kapakları, aynalar, } \\
\text { lavabolar, klozet, küvet. }\end{array}$ \\
\hline
\end{tabular}

Evde kedi, köpek ya da diğer şeklinde evcil hayvan bulunup bulunmadığını da soran sistem üzerinden site, görseller yardımı ile ütüden koltuk temizliğine kadar ekstra hizmetler de sunmaktadır (Tablo 12). Bu kısımda temizlik hizmeti verecek olan kimseye iletilmek istenen notlar da belirtilebilmektedir.

Tablo 12. evebirilazim.com'un Sağladığı Ekstra Hizmetler

\begin{tabular}{c}
\hline Ekstra Hizmetler \\
\hline Ütü \\
İç Cam \\
Buzdolabı \\
Firın Temizliği \\
Mutfak Dolap İçi \\
Balkon \\
İç-Dış Cam \\
Koltuk \\
Halı \\
Duvar
\end{tabular}

Rezervasyon kısmındaki ikinci adımda ise, ad-soy ad ve telefon numarası gibi kişisel bilgiler ile İstanbul ilinde temizlik hizmeti talep edilecek olan ilçe seçimi istenmektedir. Rezervasyonun üçüncü adımında da; kullanıcıyı temizlik hizmeti talep edilecek olan tarih ile saatlerin seçilebileceği bir ekran karşılamaktadır. Bu ekranda uygun günler beyaz, dolu günler pembe ve seçilen gün ise yeşil bir kutucuk ile gösterilmektedir (Şekil 1). 
Şekil 1. evebirilazim.com'un Tarih Bazındaki Temizlik Hizmeti Rezervasyon Ekranı

\begin{tabular}{|c|c|c|c|c|c|c|c|}
\hline \multicolumn{2}{|c|}{ Tarih seçin } & \multicolumn{2}{|c|}{ Uygun Günler } & Dolu Gü & \multicolumn{2}{|c|}{ Seçtiğiniz gün } & \\
\hline$<$ & & \multicolumn{3}{|c|}{ Haziran 2015} & & & $>$ \\
\hline pt & Sa & Ça & $\mathrm{Pe}$ & $\mathrm{Cu}$ & ct & Pz & \\
\hline 1 & 2 & 3 & 4 & 5 & 6 & 7 & \\
\hline 8 & 9 & 10 & 11 & 12 & 13 & 14 & \\
\hline 15 & 16 & 17 & 18 & 19 & 20 & 21 & \\
\hline 22 & 23 & 24 & 25 & 26 & 27 & 28 & \\
\hline 29 & 30 & & & & & & \\
\hline
\end{tabular}

Ay ve saatlerin opsiyonel olarak seçilebileceği ekranda, temizlik hizmeti talep eden kimse seçimini yaptıktan sonra rezervasyonunun son adımına geçilmektedir (Şekil 2). Seçilen saat yeşil, seçilmeyen saatler açık mavi, dolu saatler ise beyaz biçimde belirmektedir.

Şekil 2. evebirilazim.com'un Saat Bazındaki Temizlik Hizmeti Rezervasyon Ekranı

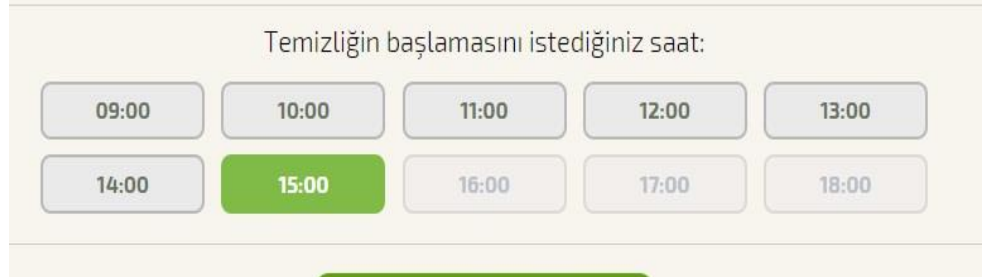

\section{REZERVASYON YAP}

E-posta adresi ve ad soyad ile şifre girilerek adres bilgilerinin de yazılmasını talep eden bu son kısımda rezervasyon detayları 1şığında kredi kartı ya da Paypal aracıllığı ile ödeme yapılıp onaylandıktan sonra rezervasyon tamamlanmaktadır. Ayrıca ödeme kısmında varsa ise kupon da kullanılabilmektedir (evebirilazim.com, 2015).

\section{3. Çevrimiçi Hizmet Sağlamada armut.com ve evebirilazim.com'un Hizmet} Temini Temelinde Yapısallıklarının Karşılaştırılması

armut.com ile evebirilazim.com internet üzerinden çevrimiçi hizmet sağlama bağlamında yeni, fakat adlarından sıkça söz ettiren internet siteleridir. armut.com ile evebirilazim.com etkin gücünü yeni medya ile gelişmiş iletişim teknolojilerinden almaktadır. Aynı amaca hizmet eden yani bireylere çevrimiçi hizmetler satın alma olanağı sunan iki site birbirleri ile bazı benzerlikler gösterirken, farklılıklara da sahip bulunmaktadır. Örneğin 
evebirilazim.com tematik olarak yalnızca temizlik hizmeti sağlarken; armut.com, evebirilazim.com'a nazaran daha fazla alanda hizmet sağlamaktadır. Öyle ki armut.com'un sağladığı hizmetler; temizlikten nakliyata, boya badanadan grafik tasarıma kadar çeşitlilik göstermektedir. Bu durumda evebirilazim.com'un yalnızca temizlik hizmeti sağlaması ile henüz yalnızca İstanbul'da faaliyet göstermesinin payı büyüktür. armut.com toplam 9 ilde hizmet sağlarken, evebirilazim.com yalnızca 1 ilde yani İstanbul'da hizmet sağlamaktadır. Bu yüzden armut.com'un daha fazla alanda çevrimiçi hizmet satın alma olanağ 1 sunması garipsenmemeli, fakat armut.com'un evebirilazim.com'a nazaran daha geniş bir coğrafyaya yayılmış olması ile çevrimiçi hizmet sağlama pratiğini daha etkili biçimde gerçekleştirdiğine de dikkat çekilmelidir.

Sitelerin her ikisi de profesyonel internet siteleri ile kullanıcılara çevrimiçi hizmet vaadi ile seslenmektedir. Yine her iki sitede de istenen hizmet ile hizmet verecek kimselerin opsiyonel olarak seçilmesi sağlanmaktadır. Bu kullanıcıyı aktif konuma getirmektedir ve yeni medya ile gelen etkileşimli iletişim sürecinde bir hayli önemlidir. Ayrıca her iki sitede hizmet talep edilen il, ilçe ve hizmet biçimleri ayrıntılı olarak sunulmaktadır. Sitelerin ikisinde de kişisel ya da kurumsal hizmet talebi gibi sınırlamalar da bulunmamakta, siteler hizmet talep eden ve hizmet sağlamak isteyen herkese açık konumda bulunmaktadır.

Buna karşın armut.com kurumsal olarak; 3D Teknik Çizim, Ofis Temizliği, Android Uygulama, PHP Programcisı, Araç Kaplama, Bina Yönetimi, SEO, Reklam Ajans1/Reklamc1, Yazılım Geliştirme, Reklam Filmi Prodüksiyon, Dijital Baskı, Tabela, Grafik Tasarım, Tanıtım Filmi, Freelance Programcı, Tercüman/Çevirmen, iPhone Uygulama, Video Editörü, iPhone Tamiri, Web Site Yaptırma, Kurumsal Kimlik Tasarımı, Web Tasarım, Led Tabela, Web, Tasarım Programlama, Logo Tasarımı, Web ve Grafik Tasarım, Matbaa Baskı, Web Yazılım ve Tasarım, Muhasebeci ve Mali Müşavirlik, Yaşam Koçu ve Ofis Taşıma hizmetleri sunduğunu belirtirken, evebirilazim.com'da böyle bir beyan yer almamaktadır.

Bununla birlikte sitelerde cinsiyet, yaş, eğitim durumu vb. sınırlamalar da bulunmamaktadır. Hem armut.com hem de evebirilazim.com üzerinden talep edilen temizlik hizmetinde kullanılacak temizlik malzemeleri, siteler ya da temizlik hizmeti verecek olan kimseler tarafindan değil, temizlik hizmeti talep eden kimse tarafindan temin edilmektedir. Yine her iki sitede ana sayfalarında kullanıcı yorumlarına yer vererek, retoriği güçlendirmek adına hareket etmekte ve müşteri memnuniyeti ile güvenilirliği ne kadar önemsediklerine dikkat çekmektedir.

Bununla birlikte, evebirilazim.com'un rezervasyon ekranı armut.com'un rezervasyon ekranına nazaran daha profesyonel ve detaylandırılmış biçimdedir ve bu durum kullanıcıya kolaylık sağlamaktadır. armut.com'da 16 kişilik bir kadro bulunurken, evebirilazim.com 4 kişilik bir çekirdek kadrodan oluşmaktadır. evebirilazim.com'da canlı destek hattı bulunurken, armut.com'da bu hat bulunmamaktadır. Sitelerden yalnızca evebirilazim.com'da ekstra hizmetler bulunmaktadır ve bahşiş uygulamasının da varlığına dikkat çekilmektedir.

armut.com profesyonel kimselerden hizmet sağlandığını beyan ederken, evebirilazim.com böyle bir beyanda bulunmamaktadır. Ayrıca armut.com'da ödeme hizmet veren kimseye bizzat yapılırken, evebirilazim.com'da ödeme hizmet verecek olan 
kimseye kredi kartı ya da Paypal aracılığg ile site üzerinden yapılmaktadır. Böylelikle hem hizmet, hem de hizmeti verecek kişi ile hizmeti alacak kişi ödeme ve rezervasyon noktasında garanti altına alınmaktadır. Yani armut.com hizmet temin etme noktasında hizmet isteyen ve hizmet vermek isteyen kimseler arasında aracilık ederken, hizmetin ödemesi noktasında aracı olmamaktadır. evebirilazim.com ise hem hizmet temin etme, hem de hizmet ödemesi noktasında bizzat aracılık yapmaktadır.

Ayrıca armut.com sosyal medyaya da büyük önem atfetmektedir. Örneğin, 2012 Eylül'de "Güldüren Üşengeçlikler Yarışıyor!!” başlığı ile Facebook hesabında (Facebook/armutcom) bireylere üşengeçlik hikayeleri ya da fotoğrafları yollamaları karşılı̆̆ında Toshiba HD Kamera kazanmak vaadi ile seslenmiştir. Seçici üyeler ise Zaytung Editörleri olarak ifade edilmiştir (girisimcianne.com, 2015).

\section{SONUÇ VE DEĞERLENDİRME}

Günümüzde yeni medyanın avantajları ve getirileri ile dünya üzerinde birçok şey gibi hizmet alma durumu da farklılaşmıştır. İnsanlar artık hizmet ya da hizmet elemanı bulmak için bireysel bir uğraş vermeye gerek duymamakta, bu ihtiyaçlarını çevrimiçi hizmeti internet üzerinden sağlayan siteler aracılığı ile temin etmeyi tercih etkemtedir. Türkiye'de dikkat çeken örnekler olan ve yeni medyanın sunduğu olanakları fark eden girişimci kimseler tarafindan kurulan armut.com ile evebirilazim.com gibi yeni birer oluşumu niteleyen başarılı oluşumlar da bu amaca hizmet etmektedir. Öyle ki, armut.com 2014 yılında düzenlenen 12. Altın Örümcek Web Ödülleri'nde ${ }^{1}$ finalistlerden olmuş, Avokado Grup Internet Servisleri sahipliğindeki armut.com, "Yaşam" kategorisinde halkın oylarıyla ikinci olmuştur (altinorumcek.com, 2015).

Çevrimiçi hizmet sağlama uygulaması Türkiye için yeni bir yönelim olsa da armut.com ile evebirilazim.com gibi siteler ile adından söz ettirmeye başlamış ve aslında iletişim teknolojilerinin olanak ve yenilikleri ile gelişecek olan potansiyel bir hizmet ağını nitelemiştir.

Türkiye'de faaliyet gösteren ve bireyler için herhangi bir hizmet konusunda ustalardan ücretsiz teklif toplayan ve bunları hem hizmet arayan hem de hizmet sunan kimseler ile buluşturan ve sitesindeki üyelerin kendilerine bağlı çalışan kimseler olmadığını söyleyen armut.com, kendi ifadesi ile "Eskiden tanıdıklara sorarak, sarı sayfalara bakarak, telefonda dil dökerek bulduğunuz boyacı, fotoğrafçı ya da evden eve nakliyat gibi hizmetlerin en iyi profesyonellerini çok daha kolay bulmanızı" sağlamaktadır (armut.com, 2015).

Eğer temizlikten nakliyata hatta doğum fotoğrafçılığına kadar hizmet sunan armut.com üzerinden boyacı ya da badana ustası arıyor iseniz; boyanacak ev ya da odanın metrekaresi, kaç oda olduğu, tavanların boyanıp boyanmayacağı ya da boyanın markası ile niteliklerini belirtebilmektesiniz. Böylelikle akılda soru işareti kalmayacak şekilde hizmet sağlayacak kimseye talepler iletilebilmekte ve iletişime geçilebilmektedir.

evebirilazim.com da tıpkı armut.com gibi detaylı biçimi ile çevrimiçi hizmet sağlama noktasında kullanıcılara samimi ve ayrıntılı yönlendirmeler ile seslenmektedir. Betimleyici ve keşfedici bir araştırma olan bu çalışmada, armut.com 39 ilçe ile en fazla 
İstanbul'da ve 2 ilçe ile de en az Eskişehir'de hizmet sağladığı tespit edilmiştir. Dolayısı ile armut.com'un hizmet talep eden ve hizmet sağlayan kimseleri genellikle büyük şehirlerde daha fazla buluşturduğu görülmektedir. evebirilazim.com ise yalnızca İstanbul'da ve sadece temizlik alanında hizmet verdiğinden armut.com'a göre daha az etkin biçimde çevrimiçi hizmet sağlamaktadır.

Hizmet veren kimse ile hizmet konusu, detaylar ve ödemeyi görüşmeyi bireylere bırakan armut.com, ödeme noktasında aracı olmadığına da dikkat çekmektedir. armut.com üzerinden teklif toplamanın ücretsiz olması sitenin kitle kaynaklı şekilde çalıştığına işaret etmektedir. Kitle kaynaklı (crowdsourced) ${ }^{2}$ şekilde çalışan yani çok sayıda kullanıcı ile herhangi bir konuda sorun çözümüne katkı sağlamak isteyen kimseleri çevrimiçi olarak buluşturan armut.com, Freelance Programc1/Yazılımcı ve Freelance Grafiker Grafik Tasarım gibi hizmetler sunduğundan, yeni medya ile yaşanan meslek profesyonelliği değişim ve dönüşümlerini de desteklemektedir. Bununla birlikte ödeme noktasında hizmet veren ile talep eden arasında bir köprü görevi gören evebirilazim.com da, kitle kaynaklı bir biçimde çalışmakta ve hizmet talep eden ile hizmet vermek isteyen kimseleri birbirleri ile buluşturmaktadır.

Öyle görünüyor ki iletişim teknolojilerinin hemen her gün gebe olduğu yenilikler kapsamında çevrimiçi hizmet satın alma ve sağlama pratiği gelişecek ve daha da yaygınlaşacaktır. Türkiye'de başarılı ve yeni örnekler olan armut.com ve evebirilazim.com gibi sitelerin sayısı daha da artacak, söz konusu sitelere belki de yenileri eklenecektir.

Ayrıca, armut.com büyük ölçüde gelişmiş ve kurumsallaşmış durumda olsa da her geçen gün hizmet ağına yenilikler katması beklenmektedir. Mevcut durumda sadece İstanbul'da hizmet veren evebirilazim.com da hizmet sayısı ile hizmet sağladığı coğrafyayı genişletmesi, bireylerin çevrimiçi hizmet alma pratiklerine profesyonelleşmiş yapısı ve yaygınlaşmış yeni ve etkili hizmet sağlama uygulamaları ile daha büyük ve önemli katkılarda bulunması beklenmektedir.

\section{NOTLAR}

${ }^{1}$ Altın Örümcek Web Ödülleri kendi beyanlarına göre; "Doruk Net tarafindan internet teknolojisi kullanılarak gerçekleştirilen başarılı projelerin hak ettiği yeri bulması ve bu alanda yapılacak yatırımın özendirilmesi amacıyla düzenlenmektedir" (altinorumcek.com, 2015).

${ }^{2}$ Ayrıntılı bilgi için bkz. Howe (2006).

\section{KAYNAKÇA}

Aday, S., Farrell, H., Lynch, M., Sides, J., \& Freelon, D. (2012). Blogs and Bullets II: New Media and Conflict after the Arab Spring. Washington: United States Institute of Peace.

Ahn, J. (2013). What Can We Learn from Facebook Activity? Using Social Learning Analytics to Observe New Media Literacy Skills. In Proceedings of the third 
international conference on learning analytics and knowledge (LAK '13), pp. 135144, April 8-12, Leuven, Belgium.

Altinorumcek.com (2015). Altın Örümcek WEB Ödülleri. (Erişim: 02.06.2015), http://altinorumcek.com/sonuclar/12-altin-orumcek/

Armut.com. (2015). Hakkımızda. (Erişim: 31.05.2015), http://armut.com/hakkimizda

Carpenter, C., \& Drezner, D. W. (2010). International Relations 2.0: The Implications of New Media for an Old Profession. International Studies Perspectives, 11(3), 255-272. doi: 10.1111/j.1528-3585.2010.00407.x

Crosbie, V. (1998). What is New Media?. (Erişim: 16.11.2015), www.sociology.org.uk/as4mm3a.doc

Evebirilazim.com (2015). Hakkımızda. (Erişim: 02.06.2015), https://www.evebirilazim.com/hakkimizda

Fuchs, C. (2012). The political economy of privacy on Facebook. Television \& New Media, 13(2), 139-159.

Garde-Hansen, J. (2009). MyMemories?: Personal Digital Archive Fever and Facebook. In Save As... Dijital Memories. Garde-Hansen, J., Hoskins, A. \& Reading, A. (Eds). pp. 135-150. Basingstoke: Palgrave MacMillian.

Girişimcianne.com. (2012). Armut’ta güldüren üşengeçlikler yarışıyor!. (Erişim: 04.06.2015), http://girisimcianne.com/2012/09/06/armutta-gulduren-usengeclikleryarisiyor/

Hampton, K., Rainie, R., Lu, W., Dwyer, M., Shin, I., \& Purcell, K. (2014). Social media and the 'Spiral of Silence'. Washington, DC.: Pew Research Center. (Erişim: 23.11.2015), http://www.pewinternet.org/files/2014/08/PI_Social-networks-anddebate_082614.pdf

Howe, J. (2006). The rise of crowdsourcing. Wired magazine, 14(6), 1-4.

Krippendorff, K. (2004). Content Analysis: An Introduction to Its Methodology. UK: Sage Publications Inc.

Kuyucu, M. (2015). Web 2.0 Haçlı Seferleri: Twitter ile Ana Akım Medyanın Erişim Savaşı. (Ed. Selva Ersöz Karakulakoğlu \& Özge Uğurlu), İletişim Çalışmalarında Dijital Yaklaşımlar, (ss. 145-181). Ankara: Heretik Yayıncılık.

Liebelson, D. (2014). MAP: Here Are the Countries That Block Facebook, Twitter, and YouTube. Mother Jones.

Manovich, L. (2001). The Language of New Media. Leonardo Book Series, London: MIT Press.

Papacharissi, Z. (2009). The virtual geographies of social networks: a comparative analysis of Facebook, LinkedIn and ASmallWorld. New Media \& Society, 11(1-2), 199-220. doi: 10.1177/1461444808099577 
Sawyer, R. (2011). The Impact of New Social Media on Intercultural Adaptation. Senior Honors Projects. Paper 242. (Erişim: 17.11.2015) http://digitalcommons.uri.edu/srhonorsprog/242

Sorapure, M. (2004). Five Principles of New Media: Or, Playing Lev Manovich, Kairos $8(2), 1-7$.

Turner, F. (2009). Burning Man at Google: a cultural infrastructure for new media production. New Media \& Society, 11(1-2), 73-94. 
Yeni Medyanın Gündelik Yaşama Etkileri: "armut.com" ve "evebirilazim.com" Örnekleri ile Çevrimiçi Hizmet Satın Alma Pratiği 